\title{
REPREZENTĂRI ALE FEMINITĂȚII ÎN POEZIA BASARABEANĂ CONTEMPORANĂ
}

\author{
OXANA GHERMAN \\ Institutul de Filologie Română „B. P.-Hasdeu” al MEC
}

\begin{abstract}
Rezumat. In prezentul articol sunt cercetate modalitățile de reprezentare estetică a feminității în textele poetice ale lui Emilian Galaicu-Păun, Nicolae Popa, Irina Nechit, Maria Pilchin, Maria Șleahtițchi, Radmila Popovici, Rodica Gotca, Veronica Ștefăneț, Moni Stănilă. În poezia supusă analizei, femeia este surprinsă in câteva ipostaze fundamentale: ca ființă spirituală, receptivă la suflul lumii, în conexiune cu universul și cu fințta divină, ca alcătuire trupească, în raport cu celălalt - în ipostază erotică, maternă, în cadrul familial și în context social. Se propune o abordare comparativă a unor secvențe poetice, acordând atenție trăsăturilor prin care personajele feminine se individualizează de la autor la autor, dar și punctele în care converg percepțiile asupra feminității.
\end{abstract}

Cuvinte-cheie: poezie, femeie, feminitate, imagine artistică, expresie.

Abstract. The article investigates the ways of aesthetic representation of femininity in contemporary poetry from Bessarabia, in the work of authors as Emilian Galaicu-Păun, Nicolae Popa, Irina Nechit, Radmila Popovici, Maria Pilchin, Maria Șleahtițchi, Rodica Gotca, Veronica Ștefăneț, Moni Stănilă. In the analyzed poems, the authors reflect the image of the woman in several fundamental hypostases: as a spiritual being, receptive to the breath of the world, in constant connexion with the universe and with the divine being, as a bodily contruction, in the relation to the other - in the erotic, maternal hypostasis, in the family and social context. A comparative approach of some poetic texts is proposed, paying attention to the features which individualize the female characters from author to author, but also the points where the perceptions on femininity converge.

Keywords: poetry, woman, femininity, artistic image, expression.

Individualizate prin viziune artistică, prin specificul instrumentarului de creație și cel al unității de ton, o categorie de texte reprezentative din poezia basarabeană contemporană transfigurează estetic natura feminină. În poezie, femeia poate fi analizată fie ca personaj poetic (ca obiect al admirației, atracției, iubirii, plăcerii sau - din contra - al suferinței), fie ca eu poetic, ca subiect care se raportează lumii, care trăiește „,complexul proces de negociere între sine și natura exterioară sinelui" (Rotariu, 2016). Analizată în complexitatea raporturilor extrinseci, feminitatea își dezvăluie esența într-un variat spectru de nuanțe: ca parte a unității ființiale primordiale (E. Galaicu-Păun), în raport 
de contiguitate cu materia mișcătoare a universului (N. Popa, I. Nechit, R. Popovici), în conexiune divinitatea (M. Stănilă), în ipostază maternă (M. Şleahtițchi, M. Pilchin, R. Gotca), în relație constantă cu micul ei univers domestic sau cu anturajul social (M. Șleahtițchi, M. Pilchin), care o determină să treacă prin diverse etape ale evoluției sufletești, dar și ale degradării fizice (V. Ștefăneț, R. Gotca). Sub aspectul relaționării cu sine, vocile poetice feminine se află într-o subtilă rezonanță.

Feminitatea este reprezentată prin prisma erosului în poezia lui Emilian Galaicu-Păun, în volumele-pereche $A(I I) R h+e u$ și $A p a .3 D$ (Cartier, 2019). Construcția cvadruplă a primei cărți, $A(I I) R h+e u$, permite o analogie cu morfologia inimii. Formată din patru cavităti care, în exercițiul funcțiunii, întrețin viața unui organism, inima e condiția sine-qua-non a ființării. Considerată o iradiere a inimii, iubirea coincide cursului vital, provocând o propulsare intensă a fluxurilor sangvine. Ideea este susținută și de citatul din G. Benn, motoul volumului: „Iubirea mea puține vorbe știe:/ Ce bine-i lângă sângele tău". Adunate în formula iubirii, cele două elemente, $A(I I) R h+$ și eu, reflectă unitatea esențială dintre animus și anima, dintre trup și suflet, dintre viață și moarte.

Volumul $A(I I) R h+e u$ se deschide cu poemul Liebestod, în care iubirea este privită ca forță ce unește contrariile într-un continuum al ființării, apropie elemente aflate la mare distanță, punând diferențele în slujba coexistenței (,diferența de nivel face râul să curgă”, ,dragostea stă-n diferența de vârstă”), dar și a transcenderii. Femeia este reprezentată, în acest context, ca parte a unui întreg fizico-spiritual. În poemul OrfEuridice, al cărei titlu sugerează unitatea primordială de tip androgin, emoția se naște din străfulgerarea unui contact vizual dintre eu (,,prin frumusețe, sunt vulnerabil”) și , $t u$, toată, numai ochi”. Personajul liric evocă pierderea unei priviri care ,rătăcește de douăj’ de ani prin Paris". Iubita este obiectul unei eterne căutări sau al unei nesfârșite așteptări: „o femeie e ca o fereastră la care se așteaptă” (Liebestod). În câteva poeme care accesează datele memoriei, erosul pulsează viu în expresii ale punctelor de intersecție corporală. În esența ei ontologică, metafizică, iubirea este o aruncare în gol „de pe cel mai înalt zgârâie-nori”, un „,mers-împreună” către moarte, o apropiere de inexistență.

Erosul este strâns legat de vizual, de ochi, de acrobația privirilor și de atracția priveliștilor, iar femeia este reprezentată, metonimic, de privirea ei, care, deși ar putea „face din noapte zi” pentru cel care „se întunecă” în Chău, rămẩne o realitate dispărută, fără de care bărbatul nu are de ales decât să închidă ochii. Pierderea vederii echivalează cu o pierdere a vieții. Parisul este un loc al absenței, locul în care femeia iese din câmpul lui vizual. Construcția OrfEuridice amintește de complementaritatea Yin-Yang, trimite la mitul lui Orfeu, la încercarea de a învinge moartea prin iubire și la finalul sfâsietor pierderea femeii iubite din cauza unei singure priviri înapoi. Ideea precum că omul prins în mreaja iubirii pierde frica de moarte, unica lui frică fiind 
de a nu pierde privirea persoanei dragi, este și mesajul poemului Clin d'oeil. Viziunea despre iubire ca ax între lumina zilei și întunericul nopții, între viață și moarte, este nucleul ideatic al Poemului sabatic. Actul erotic (,,prima oară”) apare ca „o Geneză pe invers”, desfășurat într-un întuneric care li se va retrage îndrăgostiților în carne, îndepărtându-i de moarte. La Emilian Galaicu-Păun, femeia reprezintă un orizont al așteptării, un punct spre care se îndreaptă privirea, iar trupul ei e un instrument de explorare a celor mai profunde și răvășitoare senzații fizice, de cunoaștere a potențialului spiritual, de palpare a limitelor dintre viață și moarte.

În poezia lui Nicolae Popa, cuprinsă în admirabila selecție $O$ mie de ani cu faţa la soare (Arc, 2019), femeia este reprezentată ca parte a unui univers luminiscent. Fiind o particularitate definitorie a obiectelor și fenomenelor, dar și o expresie a spiritului uman, lumina se răsfrânge din mai multe direcții și se proiectează asupra fiecărei entități. Imaginea lumii pare o hologramă ce reflectă amplitudinea undelor luminoase ale unor obiecte (hlamida, batista, tifonul, slănina, posmagii, pâinea, aluatul, sarea, dinţii, floarea de lotus, norul, piatra, oglinda, mătasea, fularul alb, blana polară, ceara ş. a.), reflexiile cărora diverg şi se întretaie cu strălucirile unor fiinţe speculare, cum sunt „băutorii luminii”, îngerii, fecioarele, nimfele, lebedele, bufniţa albă ș.a. Provenite din abstractizări metaforico-simbolice sau din imaginarul mitologic, aceste ființe par lipsite de densitate, asemeni unor reflexii transcendente. În lumea lucrurilor și a personajelor speculare, femeia nu poate fi reprezentată altfel decât ca ființă ce irizează, modificând aspectul realității: „Poate s-o fi păstrat, îmi zic, vreo adiere/ din felul cum miroseai amestecată cu marea/ făcând-o mai puţin neagră şi mai mult însorită, amestecată cu Virginia Woolf, / cea dusă spre far..." (Zenitul goliciunilor). Lumina atinge cele mai profunde strune ale sensibilităţii umane, producând un variat spectru afectiv. Sunt transfigurate, în versurile lui N. Popa, o lumină a liniştii, a fericirii şi alta a fricii, înfiorării, spaimei, dar și una emanată de vibrațiile spirituale ale iubirii. Prezența femeii iubite schimbă percepțiile personajului poetic asupra lumii, prin lumina pe care o emană.

Dacă imaginarul poetic al lui Nicolae Popa este marcat de laitmotivul soarelui, reprezentările lumii fiind influențate de prevalența luminii solare, atunci în poezia Irinei Nechit (Un om de succes și alte pierderi, Prut international, 2018) remarcăm o altă sursă de lumină - una prin excelentă feminină - lumina selenară. Simțurile personajului poetic reacționează mai cu seamă la stimulentele senzoriale nocturne. Cele mai fascinante proiecții vizuale, în care apare și femeia, par a fi cele marcate de lumina selenară: „Luna pe lacul pantofilor” (El în cer), „In vasul de lut/ plutea luna plină” (Cântec de leagăn), „Muntele agățat de gheara lunii/ se îmbracă încet/ în verde.”(Carne de trandafir). Lumina lunii provoacă o feerie mistică, o atmosferă miraculoasă ce învăluie realitatea, potențând metamorfoza poetică, regenerarea eului feminin în sfera imaginară. Aureolat de lumina lunii, o lumină a contemplării tanatice 
(Gheara), eul feminin iese din temnița trupului și profită de o totală libertate, părăsește materia și planează în ,irealitatea senzorială” (Hugo Friedrich).

Pe de altă parte, femeia manifestă sensibilitate faţă de lumina celuilalt, se oglindește în alteritate, în ,tu-ul” masculin, pe care încearcă să-1 prindă în contururi clare: „Lumina se clatină în tine/ ca vinul auriu în amforă/ ți-arată drumul spre inima luminii" (Te-am fi mințit atât de frumos). În definiția lirică a Irinei Nechit, iubirea e cea mai frumoasă formă de libertate (Aleg norii cei mai leneși), de care ị̂ti poți permite să te dezici (Pălmuită dar mereu calmă). Bărbatul iubit este un furnizor de stări, care aduce în spațiul intim al femeii fragmente triste, noroioase, ghimpoase, din exterior, întinând suprafețe de care ea tinde să se mângâie (Un apartament deasupra copacilor). Femeia acceptă ființa masculină în totalitate, cu suferințele și cu plăcerile pe care i le poate produce: „nu ţin minte când începuse capul tău să mă doară şi pe mine" (Coronița).

Metamorfoza personajului feminin e reflectată în textul Elegie pentru chipul meu, în care exteriorul agresiv anulează particularităţile individuale ale eului: „Eram alcătuită din linii blânde/ însă cineva le-a şters atât de repede/ că nici n-am apucat să scot o vorbă/ să bat cu pumnul în masă/ ori să ţip ca din gură de şarpe.../ ...ochii mei mă întreabă îngroziţi/ unde-i aluniţa de pe obraz/ şi unde-s cele două priviri cu miez auriu.../...Nu mă mai recunosc". Feminitatea presupune o identitate vulnerabilă, maleabilă, care se (re)modelează conform contururilor lumii. Realitatea, cu bune și cu rele, are acces în interiorul feminin, provocând stări dintre cele mai răvășitoare (,priveliştea îmi circulă prin sânge ca morfina”), fizicul fiind ameninţat de probabilitatea unei morți premature.

În contrast cu lumina caldă a soarelui este lumina rece a zăpezii, care în poezia lui N. Popa, sugerează linişte, fericire, armonie, fiind un fenomen care pătrunde în suflet, lecuieşte, purifică, luminează („Odihnească-se în pace zăpada de pe ramuri/ în armonie cu aerul, / în armonie cu păsările”). Zăpada e un strat interpus între pământ şi cer sau între om şi divinitate (Copertina), iar, pe de altă parte, e un înveliş organic care acoperă corpul viu al pământului: "Ţin minte, jupuiam ceva în pădure./ Trăgeam de zăpadă cu ambele mâini/ ca de o blană polară" (Carne). Ca o lumină divină materializată, zăpada poate crea, naşte, produce umanul: „Până la urmă Zăpada mamă acoperind lumea/ va găsi un loc mai curat să te nască”. Apropiată de această viziune este raportarea simbolului zăpezii la spiritul matern în poezia Irinei Nechit: „,pe ulița albă/ fugea spre casă, / fulgii roiau în jurul ei, / îngerii o plesneau cu aripile, / mama mea speriată/ își pleca fruntea/ ișis strângea haina la piept, / un lanț de urme se întindea/ de la biserică/ până la tălpile ei mici” (Zăpada). Imaginea asociază lumina trupului de fecioară cu cea a reperului material al credinței; copila și biserica, legate cu „lanțul de urme” pe zăpadă, sunt două simboluri ale castității ancorate în același spațiu-timp. Poezia asociază maternitatea în devenire cu puritatea dureroasă a iernii. 
Feminitatea este asociată simbolului apei în poezia Radmilei Popovici (Apa care își bea mâinile (Junimea, 2018). Personajul poetic reprezintă natura femeii în date primare. Ca element primordial, apa relevă trăsăturile dominante ale acesteia: autoreflexivitatea, natura volatilă, dinamismul și instabilitatea, capacitatea diluantă și puterea regeneratoare. „Ființa de apă” (I. Holban) a Radmilei Popovici se identifică în totalitate cu natura, se pierde în elementele ei, îi receptează vibrațiile, răspunde freamătelor materiei. Afinitatea dintre femeie și simbolurile acvatice nu este însă un element de absolută noutate; cercetătoarea Aliona Grati identifică acest raport în poezia Magdei Isanos, menţionând că „dovadă a unei feminităţi de structură a universului poetic isanoscian este şi exploatarea, uneori aproape obsesivă, a simbolului apei. Gândirea modernă favorizează privirea subterană, sinestezică, unde femeia se înrudeşte cu apa. Nu întâmplător, ,inconştientul colectiv" a apropiat valenţele simbolice ale apei şi femeii." (Grati, 2001, p. 115). Apa exprimă esența feminității în virtutea calității ei fertilizatoare, regeneratoare, transcendente.

În poezia Radmilei Popovici, femeia e o ființă volubilă care însă se retrage în tăcerea gesturilor pure, într-o tăcere comprimată la maximum, solidificată, mai plină de sens decât limbajul, având puterea explozivă a genezei cosmice ( $(T e t a c$ ). Lipsa de cuvinte, de unități denominative, în poezia Aproape, sugerează imposibilitatea de a deosebi secvențele de timp care trec într-o succesiune fulminantă: ,duminicile se întrec/ la trecere// niciodată n-am știut/ ce nume să le dau/ sunt lipsite de caracter/ precum ultima zi/ de vară”. Timpul nu poate fi delimitat prin denominare, esența lui nu se fixează în cuvinte, ci se topește într-un flux asupra căruia omul și cuvintele, amintirile, contemplarea, nu au putere. Ultimul vers, ,încă o duminică/ nebotezată”, este o acceptare a neputinței în fața trecerii, o împăcare cu schimbările.

Degradarea, îmbătrânirea, modificarea produsă în timp este reflectată în elementele lumii, în spații (ehe brașovul), în fenomene și în oameni (cine-s). Timpul este perceput și ca posibilitate de evadare, un acces altundeva („,ălătoriile în timp îmi scad/ din umbră...”), dar și ca nucleu ce explodează, prin care se produce o dispersie a realității contemplate de om („,chiar și liniile/ celor mai drepte zile/ se frâng// atunci punctele/ se împrăștie care/ încotro"). Inevitabilul proces al îmbătrânirii devine o obsesie (babă, $m(u)$ iere), o zbatere în actul autoconservării când „timpul fuge/ împotriva sa”. Unitățile temporale se înghesuie una în alta, se comprimă într-un fluid care se scurge în conținutul lumii. În conștiința poetică, propria ființă se scindează într-o femeie a somnului continuu și alta a eternei stări de veghe (,mă durea cumplit/ să aflu că cele două/ nu se vor îmbrățișa/ niciodată în această/ conștiință"). Trăirile polarizate se materializează, se transformă în stări fizice (micuțul infarct, libertatea balonului de săpun).

Încorporată în materia lumii, femeia trăiește mai mult într-un timpul interior. Sentimentul maturității, cât și cel al îmbătrânirii sunt trăite cu gravitate, cu senzația unei pierderi, a unei demistificări, a demascării realității. Trecerea 
timpului o lasă cu deziluzia că lumea e dezbrăcată, ca și ea, de farmec, de puritatea, inocența și frumusețea originară. Revolta în fața acestui proces nu se încheie cu resemnare, perisabilitatea corpului feminin rămâne o chestiune fără soluții.

Raportul femeii cu lumea, redus la limita tăcerii, este ilustrat într-o altă cheie în textele poetice ale Mariei Șleahtițchi. Poezia realității, surprinsă, de sensibilitatea feminină, ,între stare și mișcare”, între câte i se pot întâmpla și în realitate, și în imaginație, unei femei în timp ce se scurg zilele (Poemul de luni) sau lunile (Viața mea e în semicerc), în timp ce trece viața, se întâmplă să nu ajungă în cărți. Incomparabil mai multă decât cea care se întâmplă să fie transpusă în cuvinte, poezia, ca suflu al lumii, devine o materie din care se construiesc „tăceri babilonice” (IX). În confesiunile din ciclul Scrisori către virginia woolf e justificată criza de timp care impune femeia să aleagă între pasiunea ei pentru poezie și interminabilele treburi casnice (VIII), dar și alte motive ce explică poezia „rămasă în manuscris”.

În tiparul personajului feminin al Mariei Șleahtiţchi devin evidente trăsături ale unui profil intelectual. Atentă la evoluția formelor exterioare, la mișcarea lucrurilor, predispusă spre reflecție metafizică, spre abstractizări și transpuneri teoretice ale realemelor $(X I I)$, femeia din ciclul $O$ săptămână de poeme nescrise (antologia Fragile, Chișinău, 2016) trăiește în două dimensiuni paralele - c ea a simţurilor fizice, care se alimentează din realitatea cromatică/ sonoră/ olfactivă sau sinestezică, și cea a intelectului, care se hrănește din nenumărate reproduceri teoretice/ literare ale imaginii lumii (Pastorală II). Și poemele din ciclul Oleandrii mă strigă roz includ varia referințe culturale și nenumărate accente textualiste, prefigurând imaginea unui „sine rătăcitor”, care trăiește în lumea formelor literare, un sine care se privește „din conul de umbră" al poemelor, care e mereu gata să-și „decodeze mesajul” pentru alteritatea masculină. Textele poetice se scriu cu alte texte, uzitează termeni din teoria literară, reproduc scheme arhetipale și includ nume de autori, cuvintereferință (,,contemplând un tablou/ de decembre”; ,voi ține în mâna stângă/ un buchețel de flori de mucigai/ și sârmă ghimpată" etc.). Neobișnuit e că și ipostaza maternă e redată prin reluarea conţinutului poveștii crengiene Capra cu trei iezi (,,cum mă simt/ când nu mai simt”). Oleandrii roz sunt simboluri ale trecutului privit din viitor, ale amintirii, ale recuperării unor fapte care nu vor reuși să se realizeze, între mamă și fiică, între fiică și părinți.

Un poem în care logica feminină răstoarnă miturile lumii moderne este Dumnezeu $n$-a murit, ce reflectă dimensiunile puterii materne nu doar în a orândui micul univers pe care și 1-a creat cu mâna proprie, ci și de a-și apăra cu înverșunare punctul de vedere asupra lumii, pe care o privește „,de undeva de sus/ din înălțimile văzului ei albastru din adâncurile/ credinței în echilibrul neclintit al lumii în taina ei/ firească în binele ei și în răul implacabil în limita fizică/ în infinitatea și informitatea ei metafizică". Poemele câinele nostru, dincolo, lut reanimă spiritul matern, îi scoate din faliile memoriei, care reproduc 
în tonalități idilice tabloul domestic stăpânit de mama - o ființă aproape mitologică, un centru al energiilor universale. Imaginea ei se va învălui cu alte straturi de nuanțe și semnificații în ciclul de poeme Jurnalul florii din covorul de acasă, între reluările unor secvențe obsedante dintr-o îndepărtată în timp și în spațiu copilărie la țară, în care mama și fiicele își deapănă energic existența și o împletesc asemeni ornamentelor florale din covoarele tradiționale.

Feminitatea, în percepția Mariei Șleahtițchi, se exprimă prin rezonanțe sonore în cartea Iubirea noastră e o doamnă frumoasă (2015), ce cuprinde o poezie provenită din ,amor intellectualis”, resuscitată din „memoria sângelui”, transpusă în „fugi” sonore. Poezia reia mitul (biblic, mioritic) întrun alt conţinut, devine retorică, exclamativă, muzicală (grupajul vocalizelor), accesând zone de înaltă tensiune spirituală.

Feminitatea e văzută și ca unitate a unor contradicții, a unor variate moduri de a fi: „,varianta a// sunt cea care poartă/ înlăuntru/ cuibul și oul lumii/ sunt deplină/ se dedică/ margaretei elenei/ mie/ și altor femei// variantă reflexivă// sunt un gol imens/ cu centru într-/ un cuib părăsit/ nu sunt deplină/ nu sunt!/ nu sunt!/ nu sunt!// ultima variantă// sunt cea care port/ tot ce îmi dai/ doamne/ îți aparțin.” (poem feminin). Eul poetic, deși se percepe ca fiind unul plural (proiecții ciudate (II)), își degustă periodic singurătatea și alte stări de dezagregare sau de recompunere, exteriorizate într-o manieră intertextuală (,nu credeam să-nvăț/ a fi singură vreodată”). Trăsăturile feminine se asociază celor ale unei materii grele, concentrate, puse în mișcare: „sunt brazda mov/ ce-și înalță culoarea pe/ vârtejul de aer zvelt// sunt fluviul de miere/ de tei și de salcâm/ ce se revarsă lin/ peste ochiul nesomnului” (acum). Între mirozne și ornamente orientale, între formele celor mai rafinate lucruri (mosc chihlimbar lemn de santal), între gesturi și mișcări atente, eul poetic din poezia Mariei Șleahtițchi își caută propria reflecție, propriul contur, propria aromă.

De o subtilitate uimitoare, în poezia Mariei Pilchin (Tu ești rusul cel bun, Prut internațional, 2021), sunt secvențele ce reflectă feminitatea în esența ei contradictorie: delicată și în același timp feroce. În poemul sunt femeia măritului ceapaev, personajul se percepe drept multitudine de voci și identități, de ipostaze și roluri, este o sumă a mai multor moduri de a fi femeie: „o dată pe lună/ mă gândesc la ceapaev/ și armata lui roșie/ o dată pe lună/ toate femeile casei mele/ se întorc în mine și curg// de parcă ne taie ne căsăpește/ de parcă toate războaiele lumii/ coboară prin noi la vale". Femeia se identifică în alte femei așa cum în stările sale se suprapun cele ale tuturor ființelor de același gen. Teroarea și intensitatea culorii roșii revine de mai multe ori în tabloul lumii privite prin ochii femeii, fervența trăirilor și vitalitatea naturii ei este dominată de roșul genunchilor zdreliți în copilărie, al eritrocitelor, al nașterilor, avorturilor, macilor în floare, rujului, dar și al reacțiilor instinctive cum ar fi impulsul de a-și apăra cu cruzime granițele intimității în care este închis bărbatul iubit (,o tânără cu iphone/ făcea poze soțului meu/ am vrut să scot sabia/ și să o tai ca în filmele nipone”). Feminitatea este o luptă neștiută 
de nimeni, reală și iluzorie, o luptă cu un dușman ipotetic, cu natura lucrurilor inevitabile, care este câștigată odată ce suferă mari pierderi.

Eul feminin se percepe ca o păpuşă rusească (nopți barbare), din trupul căruia uneori se desprind diverse chipuri și ipostaze din trecut (,femeia de treizeci de ani/ care mă populează sălbatică/ cadână dură nebună") sau din viitor („,bătrâna cea tristă/ de pe strada eugendoga”); e un eu care se oglindește în interior și în exterior simultan. Varietatea interioară a femeii îi permite trecerea cu ușurință dintr-o stare în alta, dintr-o ipostază în alta, adopția de roluri și măști diferite având loc și în funcție de pozițiile cerebrale ale bărbatului (vorbele cădeau gheață). Femeia își joacă cu demnitate rolurile, se ridică la nivelul unor așteptări/ nevoi, se adaptează unor condiții ale bărbatului, susținând varia aparențe vizuale, dar ea își savurează în sine falsitatea în care se complace de dragul lui (,,imi era cald îmi era bine dar nu eram ceea ce doreai/ tu să fiu eram tot eu cea caldă și sudică doar că/ purtam o blană și vorbele tale cădeau gheață”). Femeia își permite „roluri” în care își minte sau trădează bărbatul iubit în realitate (cercei cu motive grecești) sau imaginar, tocmai atunci când pare extrem de fidelă, inocentă, servilă și inofensivă: „....apoi ai sunat ți și ai zis/ - treci acasă!/ și am venit cuminte neatinsă castă" (salon du livre 2016). Ea își permite tot felul de libertăţi imaginare (câte nu știe rochia mea de mireasă) și aventuri nebănuite (o noapte cu grișakotovski), bizare și inexplicabile, dar își stabilește și principii, legi, limite în care se închide singură (eu nu-l ating pe cavalerul teuton). „Femeia pătată” de propriile frivolități și inocențe ilustrează, astfel, încă o dată, o interioritate impură, mișcătoare, haotică, predispusă la suferințe tainice, aproape neînțelese.

Femeia din poezia Mariei Pilchin reprezintă un eu uman în structura căruia se disting trăsături familiare și trăsături străine, existente și posibile, reminiscențe ale unor experiențe trecute și germeni ai unor ipostaze viitoare. Poemele din cea de-a doua parte a plachetei par a fi o trecere firească de la o atitudine xenologică spre o una xenofilă în raport cu celălalt. Atenția se îndreaptă asupra omului străin cu care fiecare dintre noi e nevoit să conviețuiască sub propria piele, un alter ego ce provoacă disconfort, frică și suspiciune. Acceptarea chipului străin este, de fapt, o acceptare a propriului eu potențial. „Arătarea” din poezia oglinda nu este o absolută alteritate, ci o ipostază necunoscută a propriei identități: „,de fiecare dată în oglindă mă privește/ o altă ființă una care îmi ascunde mereu ceva/ care știe mai mult decât știu eu". Iubind necunoscutul din sine, omului i-ar fi mai simplu să-și iubească aproapele, oricât de străin i s-ar părea.

Modul în care femeia își percepe trecerea de la o vârstă la alta este interesantă și în poezia postdouămiistă. În versurile Veronicăi Ștefăneț (Scrum, Casa de Pariuri literare, 2019), personajul poetic se reflectă în două oglinzi simultan, cea a lui „atunci” - plin de speranțe și vise, și cea a lui „acum”, zădărnicit pierderea tuturor iluziilor: „,cu un an în urmă fluturam din 
mâini/ și vibram la fiecare mişcare din exterior/ acum cronometrez viteza de evaporare a picăturii de apă pe picior/ pielea lucește în raza de soare/ am fost argint viu, acum un boț de aur mort.”; „cu câțiva ani în urmă/ un astfel de val era să mă doboare/ acum puterea asta - mă gâdilă". Diferențele denotă trecerea personajului la o altă etapă, la o altă vârstă, la o altă atitudine față de realitate, toate însă marcate de senzația degenerării. Dacă atunci este vârsta acțiunii și a interacțiunii, acum devine etapa mersului din inerție, a abandonării, a refugiului, a pasivității și indiferentei, a renunțării, a așteptării sau, în unele cazuri, a implicării în incidente nefaste (pe feed, mai țin minte ș.a.). Într-un acum nefavorabil acțiunii, atrofiat de prejudecăţi şi circumstanțe inadecvate, pulsiunile interioare ale femeii se autoreprimă. Ea simte un fel de fragilitate asociată cu lașitatea, cu trădarea de sine, dominată de nesiguranță și frică: „vreau să mă scol și să-1 îmbrățișez/ așa cum te arunci în apă după cineva care se îneacă/ fără să scoți din buzunare telefoane țigări/ sari și atât/ rămân imobilizată de frica/ să nu fie interpretat cumva/ analizez florile de pe faţa de masă/ mușcându-mi buza de ciudă/ că mama m-a născut fetiță”, ,intrând pe poarta de la moldexpo am auzit un schelălăit slab/ un boț de blană mâncat de păduchi tremura sub tufiş/ $m$-am oprit din mestecat și am revenit pe trotuar". Pornirile interioare sunt negate, devin acțiuni dorite, neîmplinite, la care personajul feminin renunță, nutrind un dezgust faţă de sine.

Procesul evoluției, al maturizării feminine este surprins într-o altă modalitate în volumul Rodicăi Gotca, Frontiere desenate în aer cu pumnul (Eikon, 2019), în care femeia, ajunsă la etapa detectării și respingerii miturilor despre lume și viață (După 50, O femeie, Sunrise), a conștientizării relațiilor superficiale și perisabile (Prietenii), simte necesitatea modificării unor raporturi. Ea retrăiește pierderea oamenilor dragi (Bunicul, Un pat de fier, Absențe, Dor), rememorează absențele care i-au marcat copilăria (Cântec de leagăn pentru tata, Tata, Dor), sfidând ireversibilitatea timpului. Ea caută, prin rememorare și regândire a trecutului, o cale de reîntoarcere în propria matrice genetică. Poezia marcată de tendința de restabilire a pierderilor, de apropiere spirituală de familie și de tot ce întregește identitatea eului.

La Rodica Gotca, maternitatea, privită ca evoluție prin succesiune fizică, devine o experiență incomparabilă. Fericirea femeii e un efect al întregirii imaginii de sine prin urmași. În lumina ei se diminuează semnificativ impactul tuturor suferințelor („Am aruncat o privire la boțitură, / la șofer, / mi-am șters palmele asudate de blugi, am mers acasă/ și am uitat de asta/ când mi-am îmbrățișat copii”). Tema maternității și procreării este abordată într-un mod neașteptat în poezia Embrionul (,Te-ai legănat jumătate de viață într-un cuvânt, / împletind din părul negru până la călcâie/ embrioane./ Unul e al meu, / pentru a mă cufunda cuminte/ în cel mai rece/ uter"), în care se conturează ideea unei maternități deficitare, nefuncționale. Ideea se dezvoltă în poemul Copii făcuţi în eprubetă (,,pe pereții de sticlă sterili din ADN/ sunt markere 
nevalabile, / frontiere în care se zbate un sex aseptic, / redus la combinări de cromozomi”). Infertilitatea, una din problemele grave ale contemporaneității, soluționată prin concepere artificială, are consecințe, în viziunea autoarei, previzibile: un viitor al oamenilor artificiali, cărora le este programată o viață artificială într-o lume sterilă și limitată.

Natura feminității este transfigurată poetic prin prisma relației cu Dumnezeu în poezia lui Moni Stănilă, în volumul Ale noastre dintru ale noastre (Casa de Editură Max Blecher, 2020). Privită ca parte a creației divine, percepțiile asupra înfățișării fizice și profilului spiritual feminin se schimbă definitiv: „Doamne Iisuse Hristoase, frumusețea mea ești Tu// și tot ce e urât eu sunt și tot ce mă înspăimântă în întuneric din inima mea scoate capul...". Femeia este o unitate complementară a binelui și frumuseții divine, a viciilor și slăbiciunilor umane. În răspăr cu imaginile idealizate, calofile, prelucrate estetic ale femeilor din literatura altor epoci (în lirica romantică, cea modernistă și neomodernistă), versurile lui Moni Stănilă dau o altă expresie feminităţii într-un triptic poetic: (1) „Femeia nu este o imagine diafană zburând peste câmpii necosite./ Femeia este muntele mic și ferm care// își duce fiul mort în brațe.”; (2) „Femeia nu este o imagine diafană zburând peste câmpii necosite./ Femeia este muntele mic și ferm care// spune: fie mie după cuvântul Tău.”; (3) „Femeia nu este o imagine diafană zburând peste câmpii necosite./ Femeia este muntele mic și ferm care// plânge la picioarele crucii”. Femeia din poezia lui Moni Stănilă menține dialogul cu divinitatea pentru a accede spre ceea ce trebuie să devină. Scăldată în infinita iubire divină, ea își lecuiește frica de moarte prin spovedanie și își recapătă forțele interioare în rugăciune. Regretele, lipsurile și neîmplinirile pe care le conștientizează femeia sunt anulate prin certitudinea că totul se întâmplă prin voința divină (,Eu de ce nu am făcut un copil, Te întreb și în inimă se face/ liniște ca/ în miezul unei pâini, uite, suntem sănătoși, noi de ce/ nu am făcut un copil, / întreb iar și stai înăuntrul meu, dar nu răspunzi/ De ce, întreb/ a treia oară. Ce zi e astăzi, ai zis, și m-am făcut mică de tot/ și nu Ți-am/ răspuns nimic"). Femeia, această ființă reflexivă și locvace, este cea care răspândește lumina cuvântului lui Dumnezeu în lume.

Constatăm, în concluzie, că femeia, ca personaj în poezia contemporană, în unele contexte discretă, grațioasă și manierată, iar în altele aproape lipsită de concupiscență, feroce, pătrunzătoare, dilematică, înclinată spre observație și conștientizare, presupune o natură umană complexă, reprezentată în diferite unghiuri ontologice sau metafizice. Vocile poetice feminine, aflate în exerciţiul autocunoașterii și autodefinirii, aparțin unor temperamente preponderent cerebrale, reci, lucide, cu puține și neînsemnate moliciuni sentimentale (nostalgii, îndoieli, regrete, compătimiri); emotivitatea feminină e acumulată și transformată într-o irepresibilă energie creatoare. 


\section{Referințe bibliografice:}

1. GALAICU-PĂUN, Emilian. $A(I I) R h+e u$. Chișinău, 2019.

2. GOTCA, Rodica. Frontiere desenate în aer cu pumnul. București, 2019.

3. GRATI, Aliona. Poezia condiției feminine. In: Metaliteratură. 2001, nr. 2, p. $112-116$.

4. POPA, Nicolae. O mie de ani cu faţa la soare. Chișinău, 2019.

5. POPOVICI, Radmila. Apa care își bea mâinile. Iași, 2018.

6. PILCHIN, Maria. Tu ești rusul cel bun. Chișinău, 2021.

7. ROTARIU, Ioana Zenaida. Feminitatea devastată de întuneric. În: Vatra. 2016, nr. 7-8, p. 59-65 [online]. Disponibil: https://revistavatra.org/2016/10/06/ioana-zenaidarotariu-feminitatea-devastata-de-intuneric/ [citat 01.10.2021].

8. NECHIT, Irina. Un om de succes și alte pierderi. Chișinău, 2018.

9. STĂNILĂ, Moni. Ale noastre dintru ale noastre. Bistrița, 2020.

10. ȘLEAHTIȚCHI, Maria. Fragile. Chișinău, 2016.

11. ȘLEAHTIȚCHI, Maria. Iubirea noastră e o doamnă frumoasă. București, 2015. 12. ȘTEFĂNET, Veronica. Scrum. București, 2019.

Notă: Articolul a fost realizat în cadrul proiectului de cercetare 20.80009.1606.03 Contexte socioculturale autohtone şi interconexiuni europene în creaţia populară şi literatura cultă din Basarabia (sec. XIX până în prezent), Institutul de Filologie Română „B. P.-Hasdeu” al MEC. 